Abstracta Iranica Abstracta Iranica

Revue bibliographique pour le domaine irano-aryen

Volume 34-35-36 | 2017

Comptes rendus des publications de 2011-2013

\title{
Uzi 'Ad. Horbat Burin (East): Remains of Buildings and a Pottery Kiln from the Persian to the Beginning of the Early Islamic Periods
}

\section{Astrid Nunn}

\section{(2) OpenEdition}

\section{Journals}

Édition électronique

URL : http://journals.openedition.org/abstractairanica/41629

DOI : 10.4000/abstractairanica.41629

ISSN : 1961-960X

Éditeur :

CNRS (UMR 7528 Mondes iraniens et indiens), Éditions de l'IFRI

Référence électronique

Astrid Nunn, "Uzi 'Ad. Horbat Burin (East): Remains of Buildings and a Pottery Kiln from the Persian to the Beginning of the Early Islamic Periods », Abstracta Iranica [En ligne], Volume 34-35-36 | 2017, document 59, mis en ligne le 15 juillet 2016, consulté le 26 septembre 2020. URL : http:// journals.openedition.org/abstractairanica/41629; DOI : https://doi.org/10.4000/abstractairanica 41629

Ce document a été généré automatiquement le 26 septembre 2020.

Tous droits réservés 


\title{
Uzi ‘Ad. Horbat Burin (East): Remains of Buildings and a Pottery Kiln from the Persian to the Beginning of the Early Islamic Periods
}

\author{
Astrid Nunn
}

\section{RÉFÉRENCE}

Uzi 'Ad. « Horbat Burin (East): Remains of Buildings and a Pottery Kiln from the Persian to the Beginning of the Early Islamic Periods ». 'Atiqot, 70, 2012, p. 80-81.

1 Ces trois pages sont un résumé de deux articles parus en hébreu dans le même périodique. Ḥorbat Burin est situé dans la partie nord de la plaine de Sharon, non loin d'un croisement de la Via Maris avec la voie est-ouest de Naplouse (Neapolis) à Césarée sur le littoral. Deux secteurs ont été ouverts révélant l'une un four (Area A), l'autre des habitations (Area B). La construction des habitations de la phase la plus ancienne, la phase $\mathrm{V}$, remontent au début de la période hellénistique. Mais sous leur fondation les remblais étaient composés de céramique achéménide.

2 Ce compte rendu concerne également une autre référence $\left(n^{\circ} 60\right)$ :

3 Hagit Torge. « Pottery from the Persian and Hellenistic Periods at Ḥorbat Burin (East)». 'Atiqot, 70, 2012, p. 82. 


\section{AUTEURS}

\section{ASTRID NUNN}

Université de Munich 